\title{
Impact of a reservoir system on benthic macroinvertebrate and diatom communities of a large Mediterranean river (lower Ebro river, Catalonia, Spain)
}

\author{
Luis Quevedo ${ }^{1, *}$, Carles Ibáñez ${ }^{2}$, Nuno Caiola ${ }^{2}$, Núria $\mathrm{Cid}^{3}$ and Henrietta Hampel ${ }^{4}$ \\ ${ }^{1}$ Escuela Superior Politécnica de Chimborazo, ESPOCH, Riobamba, Ecuador. \\ 2 IRTA Aquatic Ecosystems. Carretera Poble Nou km 5.5, 43540 Sant Carles de la Ràpita, Catalonia, Spain. \\ ${ }^{3}$ Freshwater Ecology and Management (FEM) Research Group, Departament de Biologia Evolutiva, Ecologia i \\ Ciències Ambientals, Institut de Recerca de la Biodiversitat (IRBio), Universitat de Barcelona, Diagonal 643, \\ 08028 Barcelona, Catalonia, Spain. \\ ${ }^{4}$ Laboratorio de Ecología Acuática, Departamento de Recursos Hídricos y Ciencias Naturales and Facultad de \\ Ciencias Químicas, Universidad de Cuenca, Cuenca, Ecuador. \\ * Corresponding author: lquevedo@espoch.edu.ec
}

Received: 07/05/15 Accepted: 26/02/18

\begin{abstract}
Impact of a reservoir system on benthic macroinvertebrate and diatom communities of a large Mediterranean river (lower Ebro river, Catalonia, Spain)

This study included the main hydrogeomorphic categories of the lower Ebro River and aimed to detect spatial and temporal patterns of macroinvertebrates and diatoms communities inhabiting downstream a reservoir system. We hypothesized that biological communities will reflect a gradient of alteration related to the distance from the impact (i.e., dams). Surveys conducted along five river sections $2 \mathrm{~km}$ long integrating different years and seasons were analyzed. Non-metrical Multidimensional Scaling (MDS), Similarity Percentage Analysis (SIMPER) and 1-way Analysis of Similarities (ANOSIM) were performed to assess spatial and temporal differences in community structure. The relationship between biological and environmental data was investigated with BIOENV routine and a Principal Components Analysis (PCA) was also carried out. Significant differences in the composition of the macroinvertebrate community were found between the section closest to reservoirs (E5) and the rest of the study sections; the present community was also very different of that found in previous studies carried out in the 80's and 90 's. For the case of diatoms, significant differences in community composition were only found between seasons but not between study sections. As well, indices for ecological status assessment based on both macroinvertebrates (IBMWP) and diatoms (IPS) showed lowest scores at section E5, likely caused by the impact of dams. Macroinvertebrates and diatoms responded rather differently to anthropogenic stressors in the lower Ebro River; macroinvertebrates were more sensitive to hydromorphological impacts, while diatoms were more sensitive to water quality alteration.
\end{abstract}

Key words: benthos, large Mediterranean river, damming, ecological status, Water Framework Directive

\section{RESUMEN}

Impacto de un sistema de embalses sobre las comunidades bentónicas de macroinvertebrados y diatomeas de un gran río Mediterráneo (bajo Ebro, Cataluña, España)

El presente estudio incluyó las principales categorías hidrogeomorfológicas de la parte baja del río Ebro y tuvo como objetivo detectar los patrones de distribución de macroinvertebrados y diatomeas bentónicas aguas abajo de un sistema de embalses. Se estableció la hipótesis que las comunidades biológicas reflejan un gradiente de alteración relacionado con la distancia al impacto (por ejemplo, las presas). Se analizaron muestreos realizados a lo largo de cinco tramos del río de $2 \mathrm{Km}$, integrando diferentes años y estaciones. Diversos análisis estadísticos (MDS, SIMPER, ANOSIM) fueron utilizados para evaluar las 
diferencias espaciales y temporales en las comunidades biológicas. También se analizó la relación entre los datos biológicos y ambientales con el test BIOENV y los patrones de asociación de las variables abióticas se analizaron a través de un PCA. Se encontraron diferencias significativas en la composición de las comunidades de macroinvertebrados entre la sección más cercana a los embalses y el resto de las secciones de estudio; la composición actual de éstas comunidades fue muy diferente de la encontrada en estudios de los años 80-90. En el caso de las diatomeas, solamente se encontraron diferencias significativas a nivel estacional, pero no entre secciones de estudio. Además, los indices para la evaluación del estado ecológico basados en macroinvertebrados (IBMWP) y diatomeas (IPS) mostraron puntuaciones más bajas en la sección E5, posiblemente como resultado del impacto de las presas. Los macroinvertebrados y las diatomeas respondieron de forma diferente a los factores antropogénicos en el tramo final del río Ebro; los macroinvertebrados fueron más sensibles a los impactos hidromorfológicos, mientras que las diatomeas fueron más sensibles a las alteraciones de calidad del agua.

Palabras clave: bentos, gran río Mediterráneo, embalse, estado ecológico, Directiva Marco del Agua

\section{INTRODUCTION}

Mediterranean climate regions are hotspots of biodiversity widespread in several continents and supporting similar types of ecosystems characterized by strong spatial, seasonal and year to year variation (Kondolf et al., 2012; Stamou et al., 2004). Some of these regions share as a common factor the presence of large Mediterranean rivers (e.g. Ebro in Spain, San Joaquin and Sacramento in USA, Biobío in Chile) with comparable structural and functional features and similarly influenced by climatic and geomorphic settings (Fisher, 1995; Gasith \& Resh, 1999; Gushing et al., 1995; King et al., 1988; Puckridge et al., 1998).

Large Mediterranean rivers have been extensively dammed during the last century and reservoirs have been built to regulate the variability in water supplies for agricultural irrigation and power generation (Kondolf et al., 2012). In fact they are considered to be subject to perhaps the highest levels of water infrastructure development in the world (Grantham et al., 2013). However, while streams are the most studied component of Mediterranean (and world) rivers, there is fewer research involving large rivers due to the required sampling effort, economic cost of research, methodological problems for sampling and scarcity of this type of rivers.

Biomonitoring protocols based on benthic communities are widely used for running waters worldwide (Furse, 2006; Kelly \& Whitton, 1998; Metcalfe, 1989; Quevauviller et al., 2008) and, benthic macroinvertebrates and diatoms are frequently used as bioindicators of the ecological status. By analyzing these two biological groups, both long-term and short-term changes of environ- mental conditions can be detected (Li et al., 2010).

Diatoms have been also used for river biomonitoring purposes by many authors (Chessman et al., 1999; McCormick \& Cairns Jr, 1994; Whitton et al., 1991), and several biotic indices have been successfully applied to estimate the status of river ecosystems (Eloranta \& Soininen, 2002; Goma et al., 2005; Kelly et al., 2009; Prygiel \& Coste, 1993). Macroinvertebrates also have been widely reported as bioindicators for aquatic ecosystems (Buffagni et al., 2004; Lafont, 2011; Rosenberg \& Resh, 1993; Statzner et al., 2001; Vivas et al., 2002; Oliveira \& Cortes, 2005; Varandas \& Cortes, 2010; Cortes et al., 2013) as well as indicators for the assessment of anthropogenic hydrological alterations (Dunbar et al., 2010; Gore et al., 2001; Lafont et al., 2010; Suren \& Jowett, 2006; Vivas et al., 2002). Furthermore, in several studies (Johnson et al., 2006; Soininen \& Könönen, 2004; Torrisi et al., 2010; Tupinambás et al., 2014), macroinvertebrate and diatom communities have been used together comparing different assemblage responses to different anthropogenic pressures.

The European Union has led efforts to incorporate protection to these aquatic ecosystems through the expedition of the Water Framework Directive WFD 2000/60/EC (European Commission, 2000) which commits to state members to achieve a good ecological status of water bodies. One of the criteria established for this purpose is the implementation of biomonitoring programs based on biological quality elements, including diatoms and macroinvertebrates as central elements for ecological quality assessment.

The Ebro is the largest river in Spain in terms of water discharge, and agriculture is the domi- 


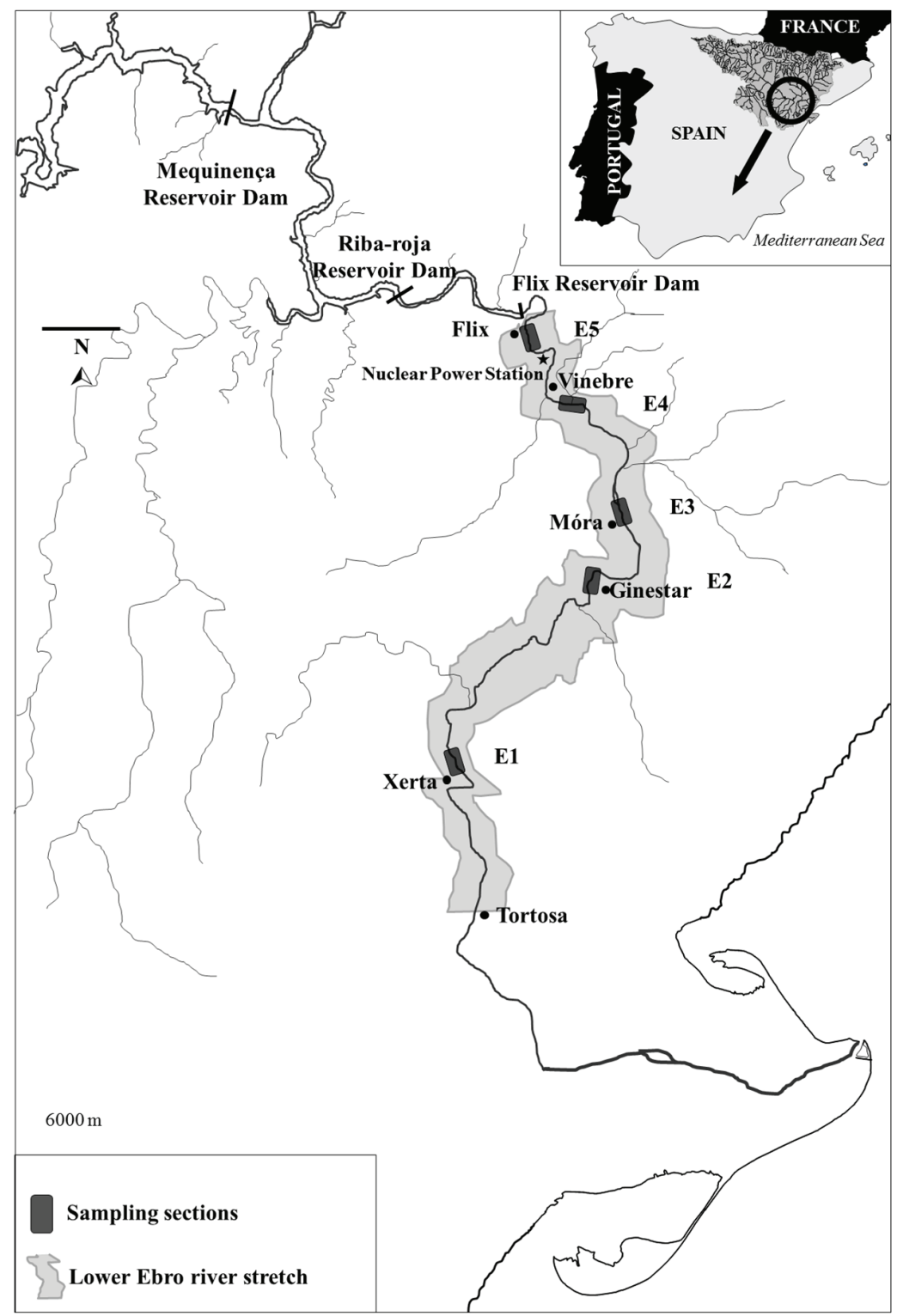

Figure 1. Map of the lower Ebro River showing the study area and the location of sampling sections. Mapa del bajo Ebro mostrando el área de estudio y la localización de las secciones de muestreo.

nant land use of its basin (Grantham et al., 2013). The lower part is regulated by a system of three reservoirs (Mequinensa, Riba-roja and Flix) which heavily modified the river hydrology, geomorphology and ecology by altering the magnitude, the timing and duration of flows, the sediment dynamics, the water temperature regime and the geochemistry (Ibáñez et al., 1996). In the Ebro River, benthic communities have been used to analyze the effects of chemical pollution, flow regulation and eutrophication (Cid et al., 2010; Muñoz \& Prat, 1996; Tornés et al., 2007) and to assess the ecological status of the river (Oscoz et al., 2007), but in the lower Ebro most of the ecological studies have focused on the estuary area (Nebra et al., 2011; Rovira et al., 2009; Rovira et al., 2012a; Rovira et al., 2012b).

The Catalan Water Agency (ACA) and the 
Hydrographical Confederacy of the Ebro (CHE) have developed periodical monitoring programs based on benthic communities (available in http://www.chebro.es and http://aca-web.gencat. cat) to determine water quality and to assess the ecological status; however, these reports do not include information neither about community structure nor the response of the communities to anthropogenic pressures (e.g. water regulation system); furthermore, most of the monitoring points are located upstream of Mequinensa and Riba-roja dams, even though, the lower part of the river evidence in great measure the consequences of the factors exerting pressure upstream.

This study aimed to detect spatial and temporal patterns of macroinvertebrates and diatom communities in the lower Ebro downstream a reservoir system, and to investigate the environmental (i.e., substrate, water quality) and anthropogenic (i.e., distance to dams) factors influencing these communities, in order to understand the ecology of large Mediterranean rivers strongly influenced by dams and other human pressures (i.e., chemical and thermal pollution). We hypothesize that biological communities will reflect a gradient of alteration related to the distance from the impact.

\section{MATERIAL AND METHODS}

\section{Study area}

The Ebro basin is located in the NE part of the Iberian Peninsula (Fig. 1), with a surface of 85 $534 \mathrm{~km}^{2}$. The Ebro River it is one of the most important tributaries to the Western Mediterranean Sea. The main river is $928 \mathrm{~km}$ long and its principal tributaries are the Segre, Aragón, Cinca, and Gállego rivers. The climate is continental in most of the basin with a transition from mountain climate at the north (Pyrenees) to Mediterranean climate at the lower part. The basin has been strongly regulated by nearly 190 dams (Batalla $e t$ al., 2004) and the main land use is agriculture, which accounts for approximately $90 \%$ of water usage for irrigating more than 1 million hectares (Ibáñez et al., 2008). The mean annual flow near the upper end of the estuary (Tortosa) was 592 $\mathrm{m}^{3 / \mathrm{s}}$ at the beginning of the $20^{\text {th }}$ century but, increasing water uses has led to a decreasing tendency since the 70 's, down to about $400 \mathrm{~m}^{3} / \mathrm{s}$ (Ibáñez et al., 1996). In the lower Ebro there are two large reservoirs, (Mequinensa and Riba-roja) built in 1964 and 1969 respectively for hydropower purposes (Ibáñez et al., 1996); downstream Riba-roja, a small reservoir (Flix) and a nuclear power station (Ascó, operating since 1984) are located. A concession of $72.3 \mathrm{~m} 3 / \mathrm{s}$ of the Ebro's flow is granted to the power station for the cooling system, that returns water $2-3{ }^{\circ} \mathrm{C}$ warmer (Prats et al., 2010). The Flix reservoir contains a large amount of sediments polluted with heavy metals such as mercury, organochlorine compounds and other toxics accumulated along 70 years due to the presence of a chemical factory (Cid et al., 2010).

This study was performed in an area (Fig. 1) that extends from the reservoir furthest downstream (Flix) to the upper limit of the estuary (Tortosa). In the study area the river is about 80 $\mathrm{km}$ long, $150 \mathrm{~m}$ wide, $5 \mathrm{~m}$ deep and the substrate is dominated by gravels.

\section{Sampling Sites}

Five (E1 to E5) sampling sections (Fig. 1) were randomly selected to perform the surveys in order to cover all the lower Ebro hydrogeomorphic variability. For this purpose aerial photographs were analyzed in order to classify the lower Ebro River in different morphological categories according to a simplified classification (Rosgen, 1994). Four morphological river categories were identified in the study area: steep stretches, moderately entrenched stretches, entrenched meanders and low gradient meanders. Then, a polyline GIS layer representing the lower Ebro River was classified according to these four morphological river categories and transformed into a point GIS layer, with equidistant points $(1 \mathrm{Km})$. Thus, the aforementioned 5 sampling sections were selected in order to ensure the coverage of the morphological variability (see Caiola et al., 2014).

Benthic surveys covering different years and seasons were conducted between 2006 and 2009, resulting in a total of 31 and 20 sampling occasions for macroinvertebrates and diatoms, respectively. Unfortunately, for logistic reasons diatoms were 
not sampled on every occasion that macroinvertebrates were collected, and never in winter. For every sampling site and occasion, physicochemical data and hydromorphological characteristics were recorded. Water velocity at $60 \%$ of total water depth was recorded with a Braystoke BFM 001 current meter; an YSI 556 multi-parameter probe was used to measure water temperature $\left({ }^{\circ} \mathrm{C}\right)$, dissolved oxygen $(\mathrm{mg} / \mathrm{l})$, oxygen saturation $(\%)$, $\mathrm{pH}$, salinity (ppt) and conductivity $(\mathrm{mS} / \mathrm{cm})$. Water depth (m) was measured using a Speedtech SM-5 depth-meter sounder. Substrate composition analysis was based on Wentworth (1922) scale including the following fractions: sand $(<2 \mathrm{~mm})$, gravel $(2-16 \mathrm{~mm})$, pebble $(16-64 \mathrm{~mm})$, cobble $(64-256 \mathrm{~mm})$, boulder $(>256 \mathrm{~mm})$ and was determined by a visual assessment of the distribution of particle size classes. Analysis of total dissolved nitrogen (TDN), soluble reactive phosphorus (SRP) and $\mathrm{SiO}_{4}$ were measured according to Koroleff (1977). Finally, the total of planktonic chlorophyll concentration was calculated using the colorimetric method (Jeffrey \& Humphrey, 1975).

\section{Macroinvertebrate sampling}

Benthic macroinvertebrates were collected in the littoral zone; sampling the central part of the river channel with a drag was not possible due to high water velocity and type of substrate (coarse gravel). The riverbed was disturbed and organisms were captured using a Surber net with a mesh size of $500 \mu \mathrm{m}$ and preserved in $4 \%$ formaldehyde. Each sample was composed by fauna collected in at least three locations along each sampling section. At the laboratory, samples were rinsed in a $500 \mu \mathrm{m}$ mesh to remove fine sediments and coarse organic material (whole leaves, twigs, algal and macrophyte mats) was thoroughly rinsed, visually inspected, and discarded. Then, the sample was evenly distributed in a flat pan of $30 \times 36 \mathrm{~cm}$ marked with a numbered grid pattern of $6 \times 6 \mathrm{~cm}$, and a random number table was used to select squares in order to get subsamples. The content of the selected square was transferred to a Petri dish, sorted and identified under an apochromatic corrected stereomicroscope Leica M165C with 16.5:1 zoom and maximum $906 \mathrm{Lp} / \mathrm{mm}$. Additional squares were added to the subsample until obtaining a minimum of 200 organisms.

Macroinvertebrates were identified according to Müller-Liebenau (1969), Nocentini and Delle Ricerche (1985), Rossaro (1982), Tachet et al. (2000) and Vieira (2000) at genus level, except for Oligochaeta which were kept at sub class level and some Diptera which were kept at sub family or tribe level. Each species was classified into feeding guilds based on Tachet et al. (2000). The feeding guilds included were the following: Absorber (A), Deposit feeder (D), Shredder (Sh), Scraper (Sc), Filter-feeder (F), Piercer (P), Predator $(\mathrm{Pr})$ and Parasite (Ps).

\section{Diatom sampling}

Benthic diatom samples were collected from submerged natural substrata (stones) by brushing their top surfaces according to the recommendations of Kelly et al. (1998). Each sample was a composite drawn from at least three stones. The suspension was fixed in $4 \%$ formaldehyde solution. At the laboratory, diatom samples were oxidized with $\mathrm{H}_{2} \mathrm{O}_{2} 30 \% V / V$ for several hours in order to remove the organic matter. $\mathrm{HCl}^{-} 37 \%$ $V / V$ was added to evaporate the carbonates from the samples, as described in Renberg (1990). Clean valves were permanently mounted with Naphrax ${ }^{\odot}$ (refractive index 1.74). The permanent slides were examined using a LEICA DMI 3000 B light microscope equipped with differential interference contrast (DIC) with a 100 times oil immersion objective $(\mathrm{n} . \mathrm{a}=1.40)$. For each sampling occasion the samples collected from each river section were processed and a minimum of 400 valves were counted each time. Identification of diatoms was done to species level mainly following Krammer and Lange-Bertalot (1986-1991) but other taxonomic and floristic works were also used when needed.

\section{Data analysis}

For both biological groups (macroinvertebrates and diatoms), descriptive community parameters were calculated for each river section: Richness (S), Shannon-Wiener's diversity index $\left(\mathrm{H}^{\prime}\right.$, as $\log _{2}$ ) and Pielou's evenness index ( $\left.\mathrm{J}^{\prime}\right)$. Ecological 
Table 1. Values of physicochemical parameters measured at each sampling section: $\mathrm{Dist}=$ distance to the dam, $\mathrm{T}=$ temperature, $\mathrm{DO}=$ dissolved oxygen, Cond $=$ conductivity, $\mathrm{Sal}=$ salinity, $\mathrm{SPR}=$ soluble reactive phosphate, $\mathrm{TDN}=$ total dissolved nitrogen, $\mathrm{TN}=$ total nitrogen, Chl $a$ = chlorophyll $a$. Valores de los parámetros físico-químicos medidos en cada sección de muestreo: Dist= distancia a la presa, $T=$ temperatura, $D O=$ oxígeno disuelto, Cond=conductividad, Sal=salinidad, SPR=fosfato reactivo soluble, TDN=nitrógeno total disuelto, $T N=$ nitrógeno total, Chl a=clorofila a.

\begin{tabular}{|c|c|c|c|c|c|c|c|c|c|c|c|c|c|c|c|c|c|}
\hline & $\begin{array}{l}\text { Dist } \\
(\mathrm{m})\end{array}$ & $\begin{array}{c}\mathrm{T} \\
\left({ }^{\circ} \mathrm{C}\right)\end{array}$ & $\mathrm{pH}$ & $\begin{array}{c}\mathrm{DO} \\
(\mathrm{mg} / \mathrm{l})\end{array}$ & $\begin{array}{l}\text { DO } \\
(\%)\end{array}$ & $\begin{array}{l}\text { Cond } \\
(\mathrm{mS} / \mathrm{cm})\end{array}$ & $\begin{array}{c}\text { Sal } \\
\text { (ppt) }\end{array}$ & $\begin{array}{l}\text { SRP } \\
(\mathrm{mg} / \mathrm{l})\end{array}$ & $\begin{array}{c}\mathrm{TDN} \\
(\mathrm{mg} / \mathrm{l})\end{array}$ & $\begin{array}{c}\mathrm{SiO}_{4} \\
(\mathrm{mg} / \mathrm{l})\end{array}$ & $\begin{array}{l}\mathrm{Chl} a \\
(\mu \mathrm{g} / \mathrm{l})\end{array}$ & $\begin{array}{l}\text { Depth } \\
\text { (m) }\end{array}$ & $\begin{array}{l}\text { Velocity } \\
(\mathrm{m} / \mathrm{s})\end{array}$ & $\begin{array}{c}\text { Cobble } \\
(\%)\end{array}$ & $\begin{array}{c}\text { Pebble } \\
(\%)\end{array}$ & $\begin{array}{c}\text { Gravel } \\
(\%)\end{array}$ & $\begin{array}{c}\text { Sand } \\
(\%)\end{array}$ \\
\hline \multicolumn{18}{|c|}{ Spring } \\
\hline E1 & 59329.03 & 17.55 & 8.01 & 9.51 & 99.85 & 894.30 & 0.53 & 0.02 & 2.31 & 0.87 & 0.69 & 0.85 & 0.34 & 00 & 67 & 33 & 00 \\
\hline E2 & 35061.43 & 19.18 & 8.00 & 9.09 & 98.63 & 704.33 & 0.39 & 0.02 & 1.96 & 0.68 & 0.45 & 0.97 & 0.34 & 12 & 74 & 14 & 00 \\
\hline E3 & 23998.65 & 18.06 & 7.99 & 9.82 & 104.00 & 873.60 & 0.51 & 0.02 & 1.81 & 0.80 & 0.73 & 0.87 & 0.28 & 10 & 48 & 30 & 12 \\
\hline E4 & 17575.58 & 20.37 & 8.06 & 8.80 & 97.73 & 674.00 & 0.36 & 0.02 & 1.53 & 0.63 & 1.08 & 0.94 & 0.03 & 03 & 46 & 35 & 16 \\
\hline E5 & 7858.15 & 15.39 & 7.93 & 8.73 & 87.78 & 818.02 & 0.51 & 0.01 & 2.38 & 0.75 & 1.46 & 0.66 & 0.17 & 44 & 39 & 17 & 00 \\
\hline \multicolumn{18}{|c|}{ Summer } \\
\hline E1 & 59329.03 & 24.60 & 8.19 & 27 & 87.78 & 8.55 & 0.49 & 0.05 & 1.62 & 0.67 & 1.20 & 0.73 & 0.36 & 00 & 67 & 33 & 00 \\
\hline E2 & 35061.43 & 25.24 & 8.32 & 6.70 & 81.80 & 1341.50 & 0.6 & 0.03 & 1.33 & 0.75 & 1.07 & 0.97 & 0.34 & 12 & 74 & 14 & 00 \\
\hline E3 & 23998.65 & 24.85 & 8.06 & 6.82 & 82.46 & 975.68 & 0.49 & 0.04 & 1.55 & 0.64 & 0.84 & 0.80 & 0.38 & 10 & 48 & 30 & 12 \\
\hline E4 & 17575.58 & 25.73 & 8.42 & 7.62 & 93.90 & 1348.90 & 0.66 & 0.02 & 1.35 & 0.71 & 1.06 & 0.94 & 0.03 & 03 & 46 & 35 & 16 \\
\hline E5 & 7858.15 & 22.56 & 7.93 & 6.88 & 80.24 & 943.41 & 0.49 & 0.04 & 1.68 & 0.66 & 1.34 & 0.65 & 0.18 & 44 & 39 & 17 & 00 \\
\hline \multicolumn{18}{|c|}{ Autumn } \\
\hline E1 & 59329.03 & 21.50 & 8.33 & 7.85 & 89.30 & 1456.33 & 0.79 & 0.03 & 1.91 & 0.53 & 1.07 & 1.03 & 0.31 & 00 & 67 & 33 & 00 \\
\hline E2 & 35061.43 & 22.58 & 8.34 & 9.08 & 105.43 & 1474.00 & 0.78 & 0.04 & 2.46 & 0.39 & 0.59 & 0.97 & 0.34 & 12 & 74 & 14 & 00 \\
\hline E3 & 23998.65 & 22.21 & 8.23 & 7.88 & 90.90 & 1463.33 & 0.78 & 0.04 & 2.50 & 0.52 & 0.88 & 1.02 & 0.35 & 10 & 48 & 30 & 12 \\
\hline E4 & 17575.58 & 22.58 & 8.34 & 9.08 & 105.43 & 1474.00 & 0.78 & 0.04 & 2.49 & 0.55 & 1.45 & 0.94 & 0.03 & 03 & 46 & 35 & 16 \\
\hline E5 & 7858.15 & 21.50 & 8.33 & 7.85 & 89.30 & 1456.33 & 0.79 & 0.04 & 2.53 & 0.44 & 2.03 & 0.66 & 0.17 & 44 & 39 & 17 & 00 \\
\hline \multicolumn{18}{|c|}{ Winter } \\
\hline E1 & 59329.03 & 12.74 & 8.18 & 10.05 & 95.33 & 55.00 & 0.51 & 0.09 & 2.46 & 0.03 & 0.80 & 1.03 & 0.31 & 00 & 67 & 33 & 00 \\
\hline E2 & 35061.43 & 12.31 & 8.19 & 9.88 & 92.07 & 1006.50 & 0.52 & 0.08 & 2.96 & 0.06 & 0.78 & 0.97 & 0.34 & 12 & 74 & 14 & 00 \\
\hline E3 & 23998.65 & 12.30 & 8.19 & 10.14 & 95.39 & 1006.50 & 0.52 & 0.04 & 2.89 & 0.13 & 1.01 & 1.02 & 0.35 & 10 & 48 & 30 & 12 \\
\hline E4 & 17575.58 & 11.60 & 8.16 & 10.23 & 94.75 & 1006.50 & 0.52 & 0.11 & 3.19 & 0.06 & 0.86 & 0.94 & 0.03 & 03 & 46 & 35 & 16 \\
\hline E5 & 7858.15 & 9.75 & 8.12 & 10.56 & 93.69 & 1018.00 & 0.52 & 0.04 & 3.09 & 0.09 & 0.60 & 0.66 & 0.17 & 44 & 39 & 17 & 00 \\
\hline
\end{tabular}

status was estimated by calculating the official indices used in Mediterranean rivers in Spain according to the WFD; these were IBMWP (Iberian Biological Monitoring Working Party) (Alba-Tercedor \& Sánchez-Ortega, 1988) for macroinvertebrates and IPS (Specific Polluosensitivity Index) for diatoms calculated by using the software OMNIDIA (Lecointe et al., 1993).

To avoid the effect of rare species, only species with a relative abundance higher than $0.05 \%$ for diatoms and $0.02 \%$ for macroinvertebrates were included in the analysis of each sample. Then, abundance data was square-root transformed in order to downweight the contribution of the most abundant taxa and similarity matrices were computed using the Bray-Curtis coefficient (Legendre \& Legendre, 1998). All environmental variables that expressed concentration were log-transformed and statistical analyses were performed using the different routines available in the Multivariate Ecological Research Software Package PRIMER V6 (Clarke
\& Gorley, 2006).

For diatoms and macroinvertebrates separately, samples and taxon abundances were ordered using Non-metrical Multidimensional Scaling (MDS) and significant differences in assemblages composition among sections and seasons were identified using 1-way Analysis of Similarities test (ANOSIM), that hypothesizes for differences between groups of samples (defined a priori) through randomization methods on a resemblance matrix. Then, in order to identify resemblances between sample groups and to identify taxa that contributed to dissimilarity among sections, a Similarity Percentage Analysis (SIMPER) was performed.

The relationship between the community structure and environmental variables was investigated with the BIOENV routine (Clarke \& Ainsworth, 1993; Clarke \& Warwick, 2001), which maximizes a rank correlation (Spearman's coefficient) between resemblance matrices derived from biotic and environmental data, iterat- 
ing for all possible combinations of environmental variables. A Spearman's coefficient value close to 0 indicates a weak relation between the community and environmental variables, whereas a value close to 1 indicates that the selected environmental variables explain the variability of the community structure. Finally, in order to illustrate patterns of association among the environmental variables, two Principal Component Analyses (PCA) were carried out with the environmental data of each biological group (because the sampling occasions were not fully coincident).

\section{RESULTS}

\section{Environmental parameters}

The average values of environmental parameters measured at each sampling section are shown in Table 1. During the study period temperature ranged between $9.7^{\circ} \mathrm{C}\left(\mathrm{E} 5\right.$, winter) and $24.8^{\circ} \mathrm{C}$ (E3, summer), and was lower in the uppermost section (E5) which is located upstream the Ascó nuclear power station and right downstream Flix dam. Dissolved oxygen showed highest values in spring (E3, $104 \%$ ) and lowest in summer (E5, 80 $\%$ ) in the uppermost section; $\mathrm{pH}$ showed the highest and lowest values in summer (E4, 8.42; E5,

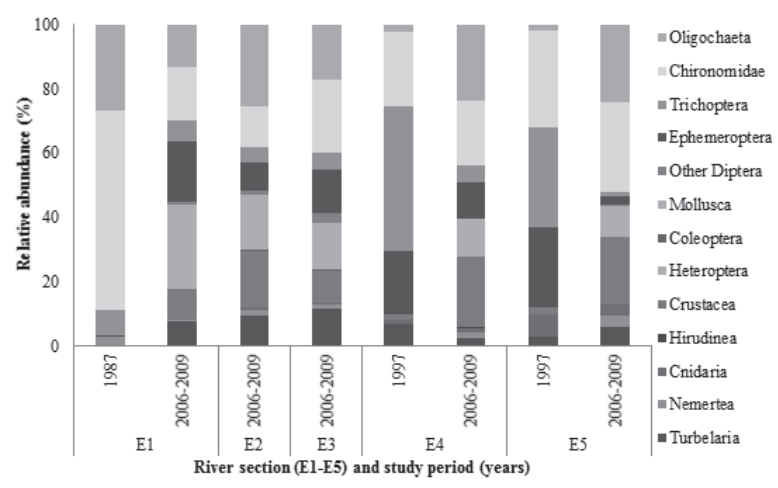

Figure 2. Macroinvertebrate community structure (\% abundance) per section in the period 2006-2009 (this study), and comparison with previous studies carried out in sections E1 (Muñoz \& Prat, 1994), E4 and E5 (LIMNOS, 1997). Estructura de la comunidad de macroinvertebrados (\% de abundancia) por sección en el periodo 2006-2009 (presente estudio), y comparación con previos estudios llevados a cabo en las secciones E1 (1987), E4 y E5 (1997).
7.93); conductivity showed a minimum in spring $(\mathrm{E} 4,674 \mathrm{mS} / \mathrm{cm})$ and a maximum in autumn (E4, $1474 \mathrm{mS} / \mathrm{cm})$; total dissolved nitrogen showed a maximum value of $3.09 \mathrm{mg} / \mathrm{l}$ (E5, winter) and a minimum of $1.33 \mathrm{mg} / 1$ (E2, summer); soluble reactive phosphorus showed a minimum of 0.01 $\mathrm{mg} / 1$ (E5, spring) and a maximum of $0.11 \mathrm{mg} / 1$ (E4, winter); $\mathrm{SiO} 4$ ranged from $0.03 \mathrm{mg} / \mathrm{l}(\mathrm{E} 1$, winter) to $0.87 \mathrm{mg} / \mathrm{l}$ (E1, spring); water chlorophyll varied from $0.45 \mu \mathrm{g} / 1$ (E2, spring) to $2.03 \mu \mathrm{g} / 1$ (E5, autumn). E5 section showed the coarsest substrata composition ( $44 \%$ cobble) in relation to sections downstream (E1 E2 E3 E4), where pebbles where the dominant fraction.

\section{Macroinvertebrate assemblages}

During the sampling period a total of 66430 individuals were collected belonging to 46 different taxa that comprised 37 genus and 36 families (Table S1, http://www.limnetica.net/en/limnetica). Artropoda was the dominant phylum and accounted for 67.78 $\%$ of the total abundance. Mollusca and Anellida contributed with $11.44 \%$ and $11.32 \%$, respectively. Chironomidae (28.19\%), Gammaridae (15.72\%) and Baetidae $(9.06 \%)$ were the most abundant families. Most of the taxa found belong to Insecta and includes: 6 mayflies (Ephemeroptera), 7 caddisflies (Trichoptera), 2 aquatic beetles (Coleoptera), 2 dragonfly and damselfly (Odonata), 10 true flies (Diptera), 1 net-winged insects (Neuroptera) and 1 true bug (Hemiptera). Macroinvertebrate community structure in each section, including a comparison with previous data available for E1, E4 and E5 is shown in (Fig. 2).

Regarding macroinvertebrate diversity (Table 2 ), the highest values of species richness were found in summer (E4, 27 taxa) and the lowest number of species (12 taxa) occurred in spring (E5) and winter (E4).

The mean values for IBMWP showed different seasonal ranges: in spring values ranged from 29 to 84 , in summer fluctuated between 52 and 112, in autumn from 37 to 60 and during winter between 42 and 83 . The highest value was found in summer at E4 indicating "very good" ecological status, whereas the lowest value was registered in spring at E5 indicating "poor" ecological status (Table 2). 
Table 2. Macroinvertebrate community descriptive parameters for each sampling section. Richness (S), Shannon-Wiener's diversity index (H', as $\log 2)$ and Pielou's evenness index (J'). Includes value and category of IBMWP index (Iberian Biological Monitoring Working Party). Parámetros descriptivos de la comunidad de macroinvertebrados de cada sección de muestreo. Riqueza (S), indice de diversidad de Shannon-Wiener (H', as log2) e indice de equidad de Pielou ( $\left.J^{\prime}\right)$. Se incluye el valor y la categoría del indice IBMWP.

\begin{tabular}{cccccc}
\hline & \multicolumn{2}{c}{$\mathrm{S}$} & $\mathrm{H}^{\prime}\left(\log _{2}\right)$ & $\mathrm{J}^{\prime}$ & \multicolumn{2}{c}{ IBMWP } \\
\hline \multicolumn{2}{c}{ Spring } & & & Value & Category \\
\hline E1 & 19 & 2.39 & 0.56 & 84 & Good \\
E2 & 17 & 1.54 & 0.38 & 55 & Moderate \\
E3 & 21 & 2.47 & 0.56 & 85 & Good \\
E4 & 14 & 1.87 & 0.49 & 40 & Moderate \\
E5 & 12 & 1.98 & 0.55 & 29 & Poor \\
\hline
\end{tabular}

Summer

\begin{tabular}{llllcc}
\hline E1 & 19 & 3.00 & 0.71 & 82 & Good \\
E2 & 20 & 3.37 & 0.78 & 82 & Good \\
E3 & 20 & 2.91 & 0.68 & 87 & Good \\
E4 & 27 & 3.70 & 0.78 & 112 & Very good \\
E5 & 17 & 2.73 & 0.67 & 52 & Moderate \\
\hline
\end{tabular}

Autumn

\begin{tabular}{llllll}
\hline E1 & 13 & 2.09 & 0.56 & 37 & Moderate \\
E2 & 17 & 2.55 & 0.62 & 60 & Moderate \\
E3 & 16 & 2.16 & 0.54 & 56 & Moderate \\
E4 & 15 & 2.50 & 0.64 & 49 & Moderate \\
E5 & 17 & 2.29 & 0.56 & 51 & Moderate \\
\hline
\end{tabular}

Winter

\begin{tabular}{lllllc}
\hline E1 & 14 & 2.75 & 0.72 & 43 & Moderate \\
E2 & 21 & 2.55 & 0.58 & 83 & Good \\
E3 & 18 & 3.22 & 0.77 & 70 & Good \\
E4 & 12 & 2.78 & 0.78 & 42 & Moderate \\
E5 & 15 & 2.85 & 0.73 & 51 & Moderate \\
\hline
\end{tabular}

In terms of trophic structure, the dominant feeding guilds were scrappers $(48.52 \%)$ followed by shredders $(24.28 \%)$ and deposit feeders ( $20.48 \%)$. Seasonal changes due to the inter-annual variability showed a dominance of scrapers during spring (32.64 \%) and summer (42.89\%), of shredders in winter (38.41\%), and deposit feeders in autumn $(47.04 \%)$. Table S1 provides a

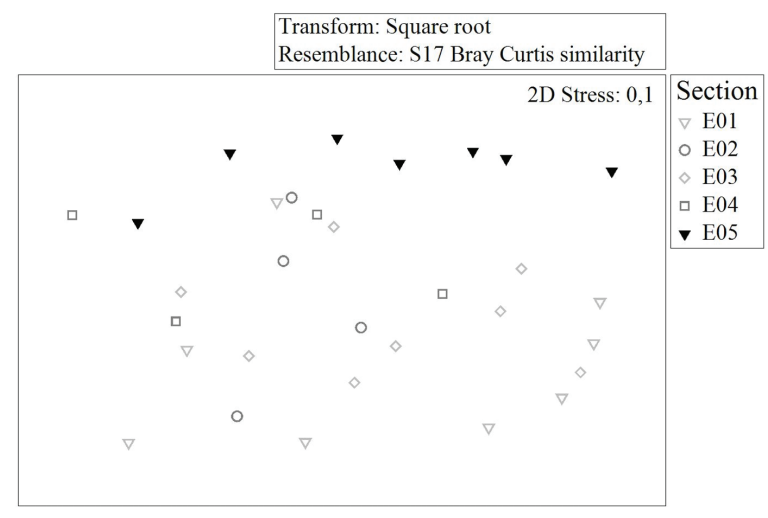

Figure 3. Two dimensional MDS plots based on Bray-Curtis similarities of square-root transformed macroinvertebrate abundance data. Samples are ordered by sites (sections). Gráfico Bidimensional MDS basado en similitudes Bray-Curtis de datos transformados a la raíz cuadrada de la abundancia de macroinvertebrados. Las muestras se ordenan por sitios (secciones).

list of macroinvertebrate taxa found over the study period including feeding guilds and the sections where each taxon was found.

Macroinvertebrate MDS analysis (Fig. 3) showed two different communities, one corresponding to the section located next to the Flix dam (E5) and another that included sections located downstream (E1 E2 E3 E4), hereafter E1-4. Significant differences in community composition were found between E5 and E1-4 (ANOSIM r: $0.218, p=0.01)$, and also among seasons (ANOSIM r: $0.433, p=0.001)$ (spring $\neq$ summer $\neq$ autumn $\neq$ winter). Fig. 3 shows the MDS ordination as a function of study sites (sections).

Similarity Percentages analysis SIMPER (Table S2, http://www.limnetica.net/en/limnetica) showed that the mean community similarity within E5 group was $42.57 \%$, and taxa that most contributed to the high similarity were Oligochaeta (21.75\%), Orthocladiinae (15.62\%), Echinogammarus (15.08 \%) and Proasellus (8.77 $\%$ ); a total of 11 taxa were necessary to accumulate $90 \%$ of similarity. The mean similarity within E1-4 group was $40.98 \%$ with a high contribution of Oligochaeta (15.84\%), Orthocladiinae (14.27\%), Corbicula (13.47\%), Echinogammarus $(9.46 \%)$ and Baetis (9.15\%); $90 \%$ of similarity in this group was obtained with 14 taxa. Furthermore the mean dissimilarity between these two groups was $64.54 \%$ with Orthocladii- 
nae, Oligochaeta, Echinogammarus, Micronecta, Dugesia, Baetis and Corbicula as the taxa with the highest contributions to dissimilarity.

BIOENV analysis showed that the combination of water temperature, substrate composition, dissolved oxygen, $\mathrm{pH}$, conductivity and distance to the dam had the strongest influence on the structure of macroinvertebrate communities ( $\rho$ $=0.378$ ). The two first axis of the PCA (Fig. 4) explained $65.4 \%$ of the total variance. The first axis $(37.5 \%)$ summarized variables displaying spatial and substrate variation, where the distance to the dam was inversely related to substrata size, which is related to the influence of the dam regulation system. The second axis (27.9\%) is likely associated to the seasonal variation, where water temperature was opposed to dissolved oxygen levels, but could be also related to the spatial variation due to the presence of dams and the nuclear power station. Fig. 4 shows the PCA ordination as a function of study sites (sections).

\section{Diatom assemblages}

A total of 124 diatom species were found during the study period. Only 67 had a relative abundance higher than $0.05 \%$ and therefore were used in the statistical analyses and are listed in Table S3, http://www.limnetica.net/en/limnetica. Some species were present in all samples and abundant

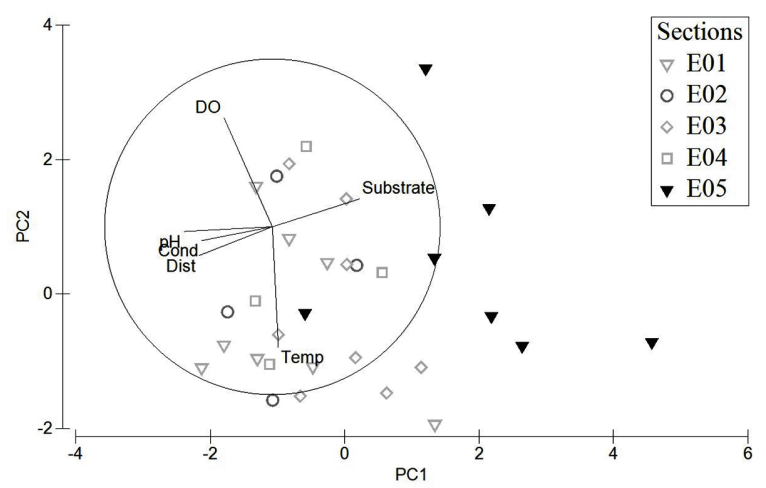

Figure 4. PCA of the macroinvertebrate data showing the ordination of sampling sections as a function of the environmental variables. Samples are ordered by sites (sections). PCA de datos de macroinvertebrados mostrando la ordenación de las secciones de muestreo en función de las variables ambientales. Las muestras se ordenan por sitios (secciones). in many of them (e.g. Amphora pediculus, Cocconeis placentula var. lineata, Nitzschia dissipata var. dissipata, N. inconspicua and N. Palea). Others, such as Navicula antonii and N. cryptotenella, though rarely exceeding $10 \%$ relative abundance, were also present throughout. Significant changes occurred in the diatom community along the year: in summer, communities were mainly dominated by Cocconeis placentula var. lineata and Nitzschia palea, and in autumn by these two species as well as Amphora pediculus. In spring the diatom community was mainly dominated by $A$. pediculus, Nitzschia dissipata var. dissipata and $N$. inconspicua.

Concerning diatom diversity (Table 3 ), there was no clear pattern among river sections. Howev-

Table 3. Diatom community descriptive parameters for each sampling section. Richness (S), Shannon-Wiener's diversity index (H', as $\log 2)$ and Pielou's evenness index (J'). Includes value and category of IPS index (Specific Polluosensitivity Index). Parámetros descriptivos de la comunidad de diatomeas de cada sección de muestreo. Riqueza (S), indice de diversidad de Shannon-Wiener ( $H^{\prime}$, as log2) e indice de equidad de Pielou $(J ')$. Se incluye el valor y la categoría del índice IPS.

\begin{tabular}{lccccc}
\hline & $\mathrm{S}$ & $\mathrm{H}^{\prime}\left(\log _{2}\right)$ & $\mathrm{J}$ & \multicolumn{2}{c}{ IPS } \\
\hline Spring & & & & Value & Category \\
\hline E1 & 27 & 3.45 & 0.74 & 14.40 & Good \\
E2 & 29 & 3.32 & 0.68 & 13.90 & Good \\
E3 & 22 & 2.62 & 0.58 & 14.87 & Good \\
E4 & 23 & 3.33 & 0.74 & 13.70 & Good \\
E5 & 26 & 2.88 & 0.62 & 12.40 & Moderate \\
\hline Summer & & & & & \\
\hline E1 & 29 & 3.75 & 0.77 & 12.00 & Moderate \\
E2 & 25 & 3.21 & 0.69 & 10.90 & Moderate \\
E3 & 30 & 4.12 & 0.84 & 12.90 & Moderate \\
E4 & 28 & 3.52 & 0.73 & 11.50 & Moderate \\
E5 & 34 & 4.18 & 0.82 & 10.40 & Moderate \\
\hline Autumn & & & & & \\
\hline E1 & 36 & 3.69 & 0.71 & 11.90 & Moderate \\
E2 & 32 & 3.74 & 0.75 & 12.10 & Good \\
E3 & 32 & 2.72 & 0.54 & 13.70 & Good \\
E4 & 35 & 3.66 & 0.71 & 10.50 & Moderate \\
E5 & 31 & 3.49 & 0.71 & 8.70 & Poor \\
\hline
\end{tabular}


er, there seemed to be a slight seasonal pattern with higher species richness in autumn. The lowest number of species occurred in spring (22 in E3).

Diatom MDS analysis showed a defined pattern of distribution at seasonal scale (Fig. 5), and significant differences were found among seasons (ANOSIM r: 0.549, $p=0.001$ ) ( spring $\neq$ summer $\neq$ autumn) but not among sections (ANOSIM r: $-0.122, p=0.91$ ). BIOENV analysis $(\rho=0.482)$ showed a significant relation between the diatom community distribution and the combination of the following environmental variables: water temperature, $\mathrm{pH}$, dissolved oxygen, soluble reactive phosphorus, $\mathrm{SiO}_{4}$, chlorophyll and total dissolved nitrogen. The two first axis of the PCA (Fig. 6) explained $61.2 \%$ of total variance; the first axis (40.9\%) summarized variables representing the seasonal variation, being water temperature opposed to dissolved oxygen and total dissolved nitrogen; and the second axis $(20.3 \%)$ summarized the effects of dam regulation on water quality, displaying $\mathrm{SiO}_{4}$ opposed to soluble reactive phosphorus, $\mathrm{pH}$ and chlorophyll. Fig. 5 and 6 show the MDS and PCA ordinations as a function of seasons, since there were not differences among sections.

Ecological status as measured by mean values of the IPS appeared to vary seasonally: in spring IPS values ranged from 12.40 to 14.40 , in summer fluctuated between 10.40 and 12.90 and

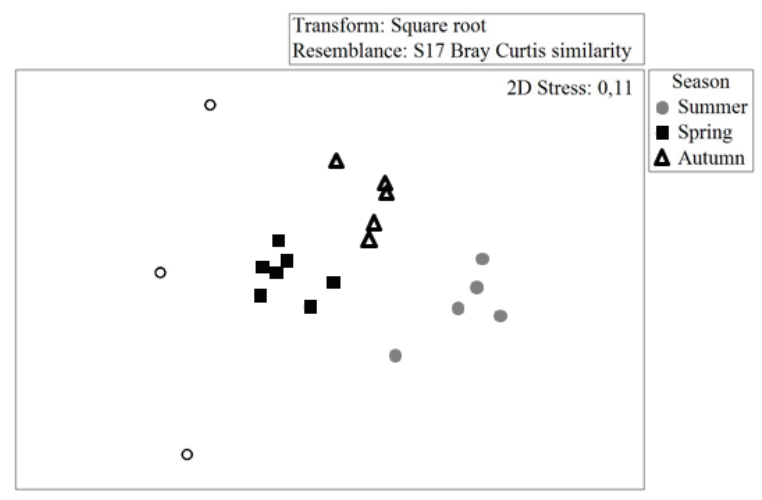

Figure 5. Two dimensional MDS plots based on Bray-Curtis similarities of square-root transformed diatom abundance data. Samples are ordered by seasons. Gráfico Bidimensional MDS basado en similitudes Bray-Curtis de datos transformados a la raíz cuadrada de la abundancia de diatomeas. Las muestras se ordenan por estaciones del año.

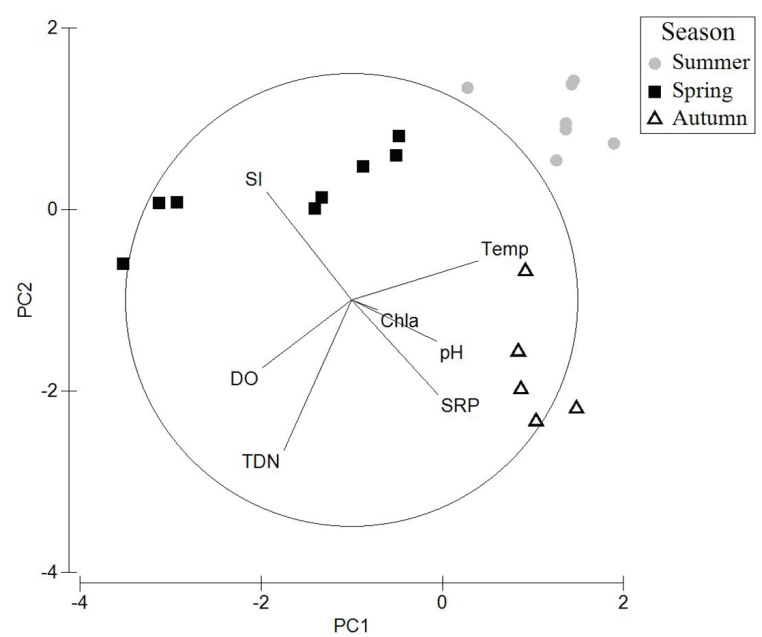

Figure 6. PCA of the diatom data showing seasonal ordination as a function of the environmental variables. Samples are ordered by seasons. PCA de datos de diatomeas mostrando la ordenación estacional en función de las variables ambientales. Las muestras se ordenan por estaciones del año.

during autumn from 8.70 to 13.70 . The highest values occurred in E3 and would indicate "good" (spring and autumn) and "moderate" (summer) ecological status. The lowest values were found in E5, indicating "poor" (autumn) and "moderate" (spring and summer) ecological status.

\section{DISCUSSION}

This work includes a characterization of benthic communities (macroinvertebrates and diatoms) in a large Mediterranean river according to environmental variables and human pressures such as damming, covering wide aspects of the morphological variability of the lower Ebro River. The sampling of biological communities was conducted in the littoral area, as it is often the case in the monitoring programs of the WFD in large rivers (including the lower Ebro River), given the technical complexity and economic cost of sampling the main river channel. At the beginning of the study the research team tried to obtain benthic samples in the channel with different types of drags but it was not possible because of high water velocity and type of dominant substrate (coarse gravel).

The annual average water temperature (17.30 
${ }^{\circ} \mathrm{C}$ ) found at $\mathrm{E} 5$ was lower than the value found at E1-4 $\left(19.59^{\circ} \mathrm{C}\right)$. The seasonal water temperature variation was influenced by the presence of a nuclear power station located downstream E5 and by reservoirs located upstream. Their co-occurrence have opposite effects on the river water during summer and winter; this pattern has been previously documented by Prats et al. (2010) who noted that in summer the cooling effect of the reservoirs and the warming effect of the nuclear power station compensated each other; whereas in winter, the warming effect of both is added. The existence of thermal pollution in the lower Ebro River has given the opportunity to study the effect of water warming on macroinvertebrates and diatoms in the vicinity of the Ascó Nuclear Power Station (Quevedo, 2015). Dissolved oxygen followed the same tendency with mean values of $87.75 \%$ and $94.67 \%$ for E5 and E1-4 respectively, and minimum summer daily values at E5 dropping down to $30 \%$; this is due to the summer stratification of the reservoirs which release water from the hypolimnion with low oxygen and high nutrient content (Sabater et al., 2008).

Benthic macroinvertebrate communities at the study area showed some significant spatial and temporal differences. The multivariate analysis defined two different communities as a function of the distance to dams: the uppermost sampling section located close to the Flix dam (E5) was significantly different from all the other sections located downstream (E1-4); this could be related to the direct influence of the Riba-roja and Flix dams on the first section of the stretch causing changes in substrate composition (coarser substrate due to erosion of fine materials) and water quality (lower oxygen values and lower temperature), as well as higher chemical pollution (heavy metals, persistent organic compounds) due to the toxic waste accumulated in Flix reservoir. Previous studies on macroinvertebrates have shown higher bioaccumulation of heavy metals and pesticides in areas of the lower Ebro River closer to the Flix dam (Cid et al., 2010; Alcaraz et $a l ., 2011)$. Thus, the present study cannot discriminate which part of the effect of reservoirs on benthic macroinvertebrates is due to hydromorphological impacts and to chemical pollution.

Results suggest that hydrogeomorphical variability classified according to the four categories of the simplified Rosgen classification (see methods) was likely not a significant factor determining the structure of benthic communities in the lower Ebro River. As mentioned before, community structure was significantly different in the section closer to the dams, but also the ecological status measured with the WFD indicators (IBMWP and IPS), suggesting that this was mostly due to the impact of dams (changes in the hydrology, water temperature, oxygen nutrients, etc.) rather than to the particular hydromorphic category of this section. However, the presence of reservoirs affect the substrate composition of the river bed downstream (Batalla et al., 2004), with more dominance of coarser materials close to the dam, but this will happen in any of the defined hydromorphological categories. This outcome is in agreement with the conceptual framework of Serial Discontinuity (Ward \& Stanford, 1983) proposed for regulated rivers, in which the distance to the dam is a determinant factor explaining differences in physical parameters and biological communities.

Changes in abundance and diversity of macroinvertebrate fauna as consequence of flow regulation has been previously reported worldwide; for instance Poff \& Zimmerman (2010) in a review of 165 papers published over the last four decades found that macroinvertebrates showed mixed responses to changes in flow magnitude, with abundance and diversity both increasing and decreasing in response to elevated flows and to reduced flows. Similar reports are found in studies from large Mediterranean rivers (e.g. Bournaud et al., 1996; Chatzinikolaou et al., 2006; Marchetti et al., 2011; Muñoz \& Prat, 1996) and around the world (Statzner et al., 1988; Poff et al., 1997; Bonada et al., 2007; Tupinambás et al., 2014, 2015) pointing the regulation system as one of the main anthropogenic alterations on macroinvertebrate communities. In fact, environmental flows are now considered as a key issue to achieve the good ecological status of superficial water bodies as required by the Water Framework Directive of the European Union (European Commission, 2012).

Although the level of nutrients has been reduced during the last decades in the lower Ebro 
River (Ibáñez et al., 2012), Chironomidae and Oligochaeta have a dominant status compared with groups as mayflies (Ephemeroptera) and caddisflies (Trichoptera). This pattern has been observed in streams and rivers with high levels of nutrients (Hawkes \& Davies, 1971; Metcalfe, 1989; Whitehurst \& Lindsey, 1990; Tupinambás et al., 2015) and, in the lower Ebro this could be also in part explained by the presence of toxic pollution in the Flix reservoir. The macroinvertebrate community along all the study area was characterized, in terms of relative abundance, by taxa that could be reflecting habitat degradation, such as Oligochaeta, Orthocladiinae, Echinogammarus, Baetis, Corbicula, Dugesia and Caenis. However, it is necessary a higher taxonomic identification to species level in order to reach an adequate ecological interpretation; for instance, Oligochaeta has been traditionally categorized as tolerant taxa, but many intolerant Oligochaeta species can be eradicated as consequence of pollution; this evidence that some Oligochaeta species are pollution tolerant but others not so much (Lafont, 2011). In fact, biotic indices based on Oligochaeta assemblages have been used in approaches for the refinement of biomonitoring programs (Lafont et al., 2010; Lafont et al., 2012).

The macroinvertebrate composition found in this study is remarkably different when compared to the community found in 1987 at E1 as reported by Muñoz \& Prat (1994) and at E4 and E5 as reported by Limnos (1997) (Fig.2). Although the methodology used was somewhat different, it is possible to recognize relevant changes in the benthic community of the lower Ebro River. Among the main changes it can be highlighted the diversification of the community, the decrease of Trichoptera (especially Hydropsyche exocellata), Chironomidae and other taxa indicating eutrophication; and the arrival of invasive species such as Dreissena polymorpha and Corbicula fluminea. Historical changes in the density and production of Ephoron virgo, a filter feeding species that inhabits in sandy and fine gravel substrates, have been previously documented by Cid et al. (2008); it was abundant in the 80's (Ibáñez et al., 1991) and early 90's (Muñoz \& Prat, 1994) but our results showed a decrease in abundance and distribution which could be associated to the reduction in phytoplankton and the spread of the macrophyte pondweed Potamogeton pectinatus in the substrate occupied by this species. The decline of phytoplankton and the spread of macrophytes in the lower Ebro River at the beginning of the present century was mostly due to a large decrease in phosphorus, but the presence of invasive bivalves and the decline in river floods and suspended sediments may also play a role (Ibáñez et al., 2012). The first reports of the zebra mussel Dreissena polymorpha and the Asian clam Corbicula fluminea in the lower Ebro River date from 2001 and 1997, respectively; these species of bivalves (filter feeders) have quickly proliferated and may compete for food resources with other native filter-feeder species; in fact, during the study period specimens were found along all the sampling sections.

According to the statistical analysis, the composition of diatom assemblages was clearly influenced by seasonal variation, and this temporal variability is related to the fluctuating along-year conditions of the lower Ebro River which involves variation in sunlight intensity, changes in water temperature and differences in nutrient concentration, as well as changes in flow regulation. However, contrary to results obtained for macroinvertebrates, there were no significant differences among sections along the study area. This is consistent with the fact that macroinvertebrates and diatoms respond rather differently to anthropogenic stressors, being macroinvertebrates more sensitive to physical changes in river habitat, while diatoms are more sensitive to water quality alterations (Hering et al., 2006; Pace et al., 2012; Soininen \& Könönen, 2004; Triest et al., 2001).

The most abundant diatom species in the study area (Amphora pediculus, Cocconeis placentula var. lineata, Nitzschia dissipata, N. inconspicua and $N$. palea) are also common further upstream in the Ebro River (http://www.chebro.es/contenido. visualizar.do?idContenido $=27971 \&$ id$\mathrm{Menu}=4101$ ) as well as the fresher parts of its estuary (Rovira et al., 2012a; Rovira et al., $2012 \mathrm{~b}$ ), and more generally in many lowland rivers of Europe (e.g. Almeida \& Feio, 2012; Urrea \& Sabater, 2009; van Dam et al., 2007). All the common species are widespread in $\alpha-, \beta$ mesosaprobous waters (van Dam et al., 1994). 
Seasonal changes in diatom communities have also been found in rivers elsewhere (e.g. Gomà et al., 2005; Leira \& Sabater, 2005; Martínez de Fabricius et al., 2003; Sherwood et al., 2000; Soininen \& Eloranta, 2004). Changes are bound to occur in diatom communities during the year as a result of variation in light intensity, day-length, temperature and life cycles of grazers, but an extra factor in some Mediterranean rivers (e.g. Ebro, Po, Rhône) is the marked seasonal variation in flow as a result of snow-melt in spring and low summer precipitation (exacerbated by irrigation and industrial demand). Water flow variation could be a major factor controlling the seasonal changes observed in all analysed sections, consistent with the findings of Boix et al. (2010), Martínez de Fabricius et al. (2003) and Tang et al. (2013).

From the biomonitoring point of view it is interesting that all five sections had similar communities according to ANOSIM analysis and showed similar seasonal changes; this implies that all of them are representative of the whole stretch and therefore any section could be chosen for surveillance of the ecological status. However, the IPS scores were always lowest in section $\mathrm{E}$, the section closest to the regulation system, and at times indicated "poor" ecological status (in autumn) which is consistent with macroinvertebrate IBMWP scores, where again "poor" status was recorded only in E5 (although in spring). Otherwise, diatom (IPS) and macroinvertebrate (IBMWP) indices indicated "moderate" or "good" ecological status.

The fact that in many cases the ecological status was "good" according to diatoms and macroinvertebrates does not mean that the overall ecological status, including other biological indicators, can be considered to be "good" as well. For instance, the fish community of the lower Ebro and other regulated rivers is strongly dominated by invasive species which are favored by dam regulation and river flow reduction (e.g. Bunn \& Arthington, 2002; Gido et al., 2013; Kiernan et al., 2012; Lytle \& Poff, 2004; Maceda-Veiga et al., 2010; Olden et al., 2006; Propst \& Gido, 2004; Caiola et al., 2014), and the ecological status of the lower Ebro River according to this indicator varies between "poor" and "bad" (Sostoa et al., 2010). Furthermore, the absence of reference conditions in the lower Ebro regarding the biological communities before dam construction difficult the proper ecological quality assessment; however, even when reference conditions are well established, biological communities may also shift as consequence of factors as climate change.

No significant differences in community structure of diatoms and macroinvertebrates were found in sections E1 to E4 (and also in E5 for the case of diatoms), and the reason could be in part related to the methodology used for sampling, which did not cover all the internal variability of the river ecosystem since samples were collected in wadeable areas; thereby the littoral community is well represented, but we were not able to obtain information of the communities inhabiting the river channel due to the difficulty of sampling with high water flow and coarse substrate (trials with different types of dredges did not work). In addition, as Chironomidae and Oligochaeta were the dominant taxa in the macroinvertebrate community, higher taxonomic resolution for these groups may be necessary in future studies to be able to discriminate significant differences in community composition that could be relevant for a finer characterization of the ecological status. Specific methods based on biological indicators capable of integrating responses to different impacts could be complementary in order to achieve a more comprehensive assessment of the ecological status of large rivers subject to multi-stressor conditions.

\section{CONCLUSIONS}

The regulation system seems to be a main factor determining the structure of benthic communities in the lower Ebro River, but differences in benthic communities are only found in the section located close to the dams for the case of macroinvertebrates. While, the composition of the diatom assemblages was clearly influenced by the seasonal variation but not along the study area, according to the performed statistical analyses. However, the obtained scores of indices for ecological status assessment based on macroinvertebrates but also on diatoms, tended to be 
lower in the section closest to reservoirs. It seems that these two groups responded rather differently to anthropogenic stressors; macroinvertebrates were more sensitive to physical and hydrological changes in river habitat, while diatoms were likely more sensitive to water quality alterations, but further studies need to be performed to better understand the changes in benthic communities under a multi-stressor scenario.

\section{ACKNOWLEDGEMENTS}

This study has been funded by the Government of Catalonia (Agència Catalana de 1'Aigua and Departament d'Innovació, Universitats i Empre$\mathrm{sa}$, the government of Spain (Ministerio de Educación y Ciencia, research project CGL2006-01487, Plan Nacional I+D+I) and the Secretaría de Educación Superior, Ciencia, Tecnología e Innovación (SENESCYT) of Ecuador, which provides a doctoral research fellowship to the first author and supports some research activities carried out by the second and sixth authors through its PROMETEO Program. We thank Lluís Jornet, David Mateu and Rosa Trobajo for their support in sampling and taxonomic classification of organisms.

\section{REFERENCES}

ALBA-TERCEDOR, J. \& A. SÁNCHEZ-ORTEGA. 1988. Un método rápido y simple para evaluar la calidad biológica de las aguas corrientes basado en el de Hellawell (1978). Limnetica, 4: 51-56.

ALCARAZ, C., CAIOLA, N., \& C. IBÁÑEZ. 2011. Bioaccumulation of pollutants in the zebra mussel from hazardous industrial waste and evaluation of spatial distribution using GAMs. Science of the Total Environment, 409(5): 898-904. DOI: 10.1016/j.scitotenv. 2010.11 .015

ALMEIDA, S. F. P. \& M. J. FEIO. 2012. DIATMOD: diatom predictive model for quality assessment of Portuguese running waters. Hydrobiologia, 695: 185-197. DOI: 10.1007/ s10750-012-1110-4

BATALLA, R. J., C. M. GOMEZ \& G. M. KONDOLF. 2004. Reservoir-induced hydrological changes in the Ebro River basin (NE Spain). Journal of Hydrology, 290: 117-136. DOI: 10.1016/j.jhydrol.2003.12.002

BOIX, D., E. GARCÍA-BERTHOU, S. GASCÓN, L. BENEJAM, E. TORNÉS, J. SALA, J. BENITO, A. MUNNÉ, C. SOLÀ \& S. SABATER. 2010. Response of community structure to sustained drought in Mediterranean rivers. Journal of Hydrology, 383: 135-146. DOI: 10.1016/j.jhydrol.2010.01.014 BONADA, N., M. RIERADEVALL \& N. PRAT. 2007. Macroinvertebrate community structure and biological traits related to flow permanence in a Mediterranean river network. Hydrobiologia, 589: 91-106. DOI: 10.1007/s10750007-0723-5

BOURNAUD, M., B. CELLOT, P. RICHOUX \& A. BERRAHOU. 1996. Macroinvertebrate community structure and environmental characteristics along a large river: congruity of patterns for identification to species or family. Journal of the North American Benthological Society, 15: 232-253. DOI: 10.2307/1467950

BUFFAGNI, A., S. ERBA, M. CAZZOLA \& J. L. KEMP. 2004. The AQEM multimetric system for the southern Italian Apennines: assessing the impact of water quality and habitat degradation on pool macroinvertebrates in Mediterranean rivers. Hydrobiologia, 516: 313-329. DOI: 10.1007/978-94-007-0993-5 19

BUNN, S. E. \& A. H. ARTHINGTON. 2002. Basic principles and ecological consequences of altered flow regimes for aquatic biodiversity. Environmental Management, 30: 492-507. DOI: $10.1007 / \mathrm{s} 00267-002-2737-0$

CAIOLA, N., C. IBÁÑEZ, J. VERDÚ \& A. MUNNÉ. 2014. Effects of flow regulation on the establishment of alien fish species: a community structure approach to biological validation of environmental flows. Ecological Indicators, 45: 598-604. DOI: 10.1016/ j.ecolind.2014.05.012

CID, N., C. IBÁÑEZ \& N. PRAT. 2008. Life history and production of the burrowing mayfly Ephoron virgo (Olivier, 1791)(Ephemeroptera: Polymitarcyidae) in the lower Ebro river: a comparison after 18 years. Aquatic Insects, 30: 163-178. DOI: 10.1080/ 
01650420802010356

CID, N., C. IBÁÑEZ, A. PALANQUES \& N. PRAT. 2010. Patterns of metal bioaccumulation in two filter-feeding macroinvertebrates: exposure distribution, inter-species differences and variability across developmental stages. Science of the Total Environment, 408: 2795-2806. DOI: 10.1016/j.scitotenv.2010.03. 030

CLARKE, K. \& M. AINSWORTH. 1993. A method of linking multivariate community structure to environmental variables. Marine Ecology-Progress Series, 92: 205-205. http://www.jstor.org/stable/24832527

CLARKE, K. \& R. WARWICK. 2001. Changes in marine communities: an approach to statistical analysis and interpretation. Natural Environment Research Council. Plymouth, UK.

CLARKE, K. \& R. GORLEY. 2006. PRIMER V6: user manual-tutorial. Plymouth Marine Laboratory.

CHATZINIKOLAOU, Y., V. DAKOS \& M. LAZARIDOU. 2006. Longitudinal impacts of anthropogenic pressures on benthic macroinvertebrate assemblages in a large transboundary Mediterranean river during the low flow period. Acta Hydrochimica et Hydrobiologica, 34: 453-463. DOI: 10.1002/ aheh.200500644

CHESSMAN, B., I. GROWNS, J. CURREY \& N. PLUNKETT-COLE. 1999. Predicting diatom communities at the genus level for the rapid biological assessment of rivers. Freshwater Biology, 41: 317-331. DOI: 10.1046/j.13652427.1999.00433.x

CORTES, R. M. V., S. J. HUGHES, V. PEREIRA \& S. G. VARANDAS. 2013. Tools for bioindicator assessment in rivers: The importance of spatial scale, land use patterns and biotic integration. Ecological Indicators, 34: 460-477. DOI: 10.1016/j.ecolind.2013.06.004

DUNBAR, M. J., M. L. PEDERSEN, D. CADMAN, C. EXTENCE, J. WADDINGHAM, R. CHADD \& S. E. LARSEN. 2010. River discharge and local-scale physical habitat influence macroinvertebrate LIFE scores. Freshwater Biology, 55: 226-242. DOI: 10.1111/j.1365-2427.2009.02306

ELORANTA, P. \& J. SOININEN. 2002. Ecologi- cal status of some Finnish rivers evaluated using benthic diatom communities. Journal of Applied Phycology, 14: 1-7. DOI: 10.1023/A: 1015275723489

EUROPEAN COMMISSION. 2000. Directive 2000/60/EC of the European Parliament and of the Council establishing a framework for Community action in the field of water policy. Official Journal of the European Communities. L327.

EUROPEAN COMMISSION. 2012. The blueprint to safeguard Europe's water resources Communication from the Commission COM(2012)673. European Commission. Brussels, Belgium.

FISHER, S. G. 1995. Stream ecosystems of the western United States. Ecosystems of the World, 22: 61-87.

FURSE, M. T. 2006. The ecological status of European rivers: evaluation and intercalibration of assessment methods. Hydrobiologia, 566: 1-2. DOI: 10.1007/s10750-006-0113-4

GASITH, A. \& V. H. RESH. 1999. Streams in Mediterranean climate regions: abiotic influences and biotic responses to predictable seasonal events. Annual Review of Ecology and Systematics, 30: 51-81. DOI: 10.1146/ annurev.ecolsys.30.1.51

GIDO, K. B., D. L. PROPST, J. D. OLDEN, K. R. BESTGEN \& J. ROSENFELD. 2013. Multidecadal responses of native and introduced fishes to natural and altered flow regimes in the American Southwest. Canadian Journal of Fisheries and Aquatic Sciences, 70: 554-564. DOI: 10.1139/cjfas-2012-0441

GOMÀ, J., F. RIMET, J. CAMBRA, L. HOFFMANN \& L. ECTOR. 2005. Diatom communities and water quality assessment in Mountain Rivers of the upper Segre basin (La Cerdanya, Oriental Pyrenees). Hydrobiologia, 551: 209-225. DOI: 10.1007/s10750-005-4462-1

GORE, J. A., J. B. LAYZER \& J. MEAD. 2001. Macroinvertebrate instream flow studies after 20 years: a role in stream management and restoration. Regulated Rivers: Research \& Management, 17: 527-542. DOI: 10.1002/rrr.650

GRANTHAM, T. E., R. FIGUEROA \& N. PRAT. 2013. Water management in Mediterranean river basins: a comparison of manage- 
ment frameworks, physical impacts, and ecological responses. Hydrobiologia, 719: 451-482. DOI: 10.1007/s10750-012-1289-4

GUSHING, C., K. CUMMINS \& G. MINSHALL. 1995. River and stream ecosystems. Elsevier, Amsterdam, The Netherlands.

HAWKES, H. A. \& L. J. DAVIES. 1971. Some effects of organic enrichment on benthic invertebrate communities in stream riffles. In: The scientific management of animal and plant communities for conservation. Duffey, E. \& A. Watt (eds): 271-299. Blackwell. Oxford, UK.

HERING, D., R. K. JOHNSON, S. KRAMM, S. SCHMUTZ, K. SZOSZKIEWICZ \& P. F. VERDONSCHOT. 2006. Assessment of European streams with diatoms, macrophytes, macroinvertebrates and fish: a comparative metric-based analysis of organism response to stress. Freshwater Biology, 51: 1757-1785. DOI: $10.1111 / \mathrm{j} .1365-2427.2006 .01610 . \mathrm{x}$

IBÁÑEZ, C., R. ESCOSA, I. MUÑOZ \& N. PRAT. 1991. Life cycle and production of Ephoron virgo (Ephemeroptera: Polymitarcidae) in the lower river Ebro (NE Spain). In: Overview and Strategies of Ephemeroptera and Plecoptera. Alba Tercedor, J. \& A. Sanchez-Ortega (eds): 483-492. Sandhill Crane Press. USA.

IBÁÑEZ, C., N. PRAT \& A. CANICIO. 1996. Changes in the hydrology and sediment transport produced by large dams on the lower Ebro river and its estuary. Regulated Rivers: Research \& Management, 12: 51-62. DOI: 10.1002/(SICI)1099-1646(199601)12:1<51:: AID-RRR376>3.0.CO;2-I

IBÁÑEZ， C., N. PRAT, C. DURAN, M. PARDOS, A. MUNNÉ, R. ANDREU, N. CAIOLA, N. CID, H. HAMPEL \& R. SÁNCHEZ. 2008. Changes in dissolved nutrients in the lower Ebro river: causes and consequences. Limnetica, 27: 131-142.

IBÁÑEZ, C., C. AlCARAZ, N. CAIOLA, A. ROVIRA, R. TROBAJO, M. ALONSO, C. DURAN, P. J. JIMÉNEZ, A. MUNNÉ \& N. PRAT. 2012. Regime shift from phytoplankton to macrophyte dominance in a large river: Top-down versus bottom-up effects. Science of the Total Environment, 416: 314-322. DOI: 10.1016/j.scitotenv.2011.11.059

JEFFREY, S. \& G. HUMPHREY. 1975. New spectrophotometric equations for determining chlorophylls a, b, c1 and c2 in higher plants, algae and natural phytoplankton. Biochem Physiol Pflanzen, 167: 191-194. DOI: 10.1016/S0015-3796(17)30778-3

JOHNSON, R. K., D. HERING, M. T. FURSE \& P. F. VERDONSCHOT. 2006. Indicators of ecological change: comparison of the early response of four organism groups to stress gradients. Hydrobiologia, 566: 139-152. DOI: 10.1007/978-1-4020-5493-8_10

KELLY, M., A. CAZAUBON, E. CORING, A. DELL'UOMO, L. ECTOR, B. GOLDSMITH, H. GUASCH, J. HÜRLIMANN, A. JARLMAN \& B. KAWECKA. 1998. Recommendations for the routine sampling of diatoms for water quality assessments in Europe. Journal of Applied Phycology, 10: 215-224. DOI: 10.1023/A:1008033201227

KELLY, M. G. \& B. A. WHITTON. 1998. Biological monitoring of eutrophication in rivers. Hydrobiologia, 384: 55-67. DOI: 10.1023/A:1003400910730

KELLY, M., C. BENNETT, M. COSTE, C. DELGADO, F. DELMAS, L. DENYS, L. ECTOR, C. FAUVILLE, M. FERRÉOL \& M. GOLUB. 2009. A comparison of national approaches to setting ecological status boundaries in phytobenthos assessment for the European Water Framework Directive: results of an intercalibration exercise. Hydrobiologia, 621: 169-182. DOI: 10.1007/s10750-008-9641-4

KIERNAN, J. D., P. B. MOYLE \& P. K. CRAIN. 2012. Restoring native fish assemblages to a regulated California stream using the natural flow regime concept. Ecological Applications, 22: 1472-1482. DOI: 10.1890/11-0480.1

KING, J., J. DAY, P. HURLY, M. HENSHALL-HOWARD \& B. DAVIES. 1988. Macroinvertebrate communities and environment in a southern African mountain stream. Canadian Journal of Fisheries and Aquatic Sciences, 45: 2168-2181. DOI: 10.1139/f88-252

KONDOLF, G. M., K. PODOLAK \& T. E. GRANTHAM. 2012. Restoring Mediterranean-climate rivers. Hydrobiologia, 719: 527-545. DOI: 10.1007/s10750-012-1363-y 
KOROLEFF, F. 1977. Simultaneous persulfate oxidation of phosphorus and nitrogen compounds in water. In: Report of the Baltic Intercalibration Worshop. Grasshoff, K. (ed.) 52-53. Annex Interim Commission for the Protection of the Environment of the Baltic Sea.

KRAMMER, K., H. LANGE-BERTALOT, N. BATE, A. PODZORSKI \& J. BUKOWSKA. 1986-1991. Bacillariophyceae 1Teil: Naviculaceae (1986); 2 Teil: Bacillariaceae, Epithemiaceae, Surirellaceae, (1988); 3 Teil: Centrales, Fragilariaceae, Eunotiaceae, (1991a); 4 Teil: Achnanthaceae, Kritische Ergäänzungen zu Navicula (Lineolatae) und Gomphonema Gesamtliteraturverzeichnis, (1991b). In: Süßwasserflora von Mitteleuropa Ettl, H., J. Gerloff, H. Heying \& D. Mollenhauer (eds): 1-876. Gustav Fischer Verlag. Stuttgart.

LAFONT, M. 2011. Towards ecohydrological approach of biomonitoring in running waters. Ecohydrology \& Hydrobiology, 11: 9-22. DOI: 10.2478/v10104-011-0032-5

LAFONT, M., C. JÉZÉQUEL, A. VIVIER, P. BREIL, L. SCHMITT \& S. BERNOUD. 2010. Refinement of biomonitoring of urban water courses by combining descriptive and ecohydrological approaches. Ecohydrology \& Hydrobiology, 10: 3-11. DOI: $10.2478 / \mathrm{v} 10104-009-0047-3$

LAFONT, M., G. TIXIER, J. MARSALEK, C. JÉZÉQUEL, P. BREIL \& L. SCHMITT. 2012. From research to operational biomonitoring of freshwaters: a suggested conceptual framework and practical solutions. Ecohydrology \& Hydrobiology, 12: 9-20. DOI: 10.2478/v10104-012-0004-4

LECOINTE, C., M. COSTE \& J. PRYGIEL. 1993. "Omnidia": software for taxonomy, calculation of diatom indices and inventories management. Hydrobiologia, 269: 509-513. DOI: 10.1007/BF00028048

LEGENDRE, P. \& L. LEGENDRE. 1998. Numerical ecology (2nd English ed.) Elsevier. Amsterdam, The Netherlands.

LEIRA, M. \& S. SABATER. 2005. Diatom assemblages distribution in catalan rivers, NE Spain, in relation to chemical and physiographical factors. Water Research, 39: 73-82.
DOI: $10.1016 /$ j.watres.2004.08.034

LI, L., B. ZHENG \& L. LIU. 2010. Biomonitoring and bioindicators used for river ecosystems: definitions, approaches and trends. Procedia Environmental Sciences, 2: 1510-1524. DOI: 10.1016/j.proenv.2010.10.164

LIMNOS. 1997. Estudi dels efectes de l'abocament tèrmic de la central nuclear d'Ascó sobre les comunitats biolòiques. $\mathrm{N}^{\mathrm{o}}$ proyecto CE017685. Junta de Sanejament. Barcelona, Spain.

LYTLE, D. A. \& N. L. POFF. 2004. Adaptation to natural flow regimes. Trends in Ecology \& Evolution, 19: 94-100. DOI: 10.1016/j.tree.2003. 10.002

MACEDA-VEIGA, A., A. MONLEON-GETINO, N. CAIOLA, F. CASALS \& A. DE SOSTOA. 2010. Changes in fish assemblages in catchments in north-eastern Spain: biodiversity, conservation status and introduced species. Freshwater Biology, 55: 1734-46. DOI: $10.1111 / \mathrm{j} .1365-2427.2010 .02407 . x$

MARCHETTI, M. P., E. ESTEBAN, A. N. H. SMITH, D. PICKARD, A. B. RICHARDS \& J. SLUSARK. 2011. Measuring the ecological impact of long-term flow disturbance on the macroinvertebrate community in a large Mediterranean climate river. Journal of Freshwater Ecology, 26: 459-480. DOI: 10.1080/02705060.2011.577974

MARTÍNEZ DE FABRICIUS, A. L., N. MAIDANA, N. GÓMEZ \& S. SABATER. 2003. Distribution patterns of benthic diatoms in a Pampean river exposed to seasonal floods: the Cuarto River (Argentina). Biodiversity and Conservation, 12: 2443-2454. DOI: 10.1023/A:1025857715437

MCCORMICK, P. V. \& J. CAIRNS JR. 1994. Algae as indicators of environmental change. Journal of Applied Phycology, 6: 509-526. DOI: $10.1007 / \mathrm{BF} 02182405$

METCALFE, J. L. 1989. Biological water quality assessment of running waters based on macroinvertebrate communities: history and present status in Europe. Environmental Pollution, 60: 101-139. DOI: 10.1016/02697491(89)90223-6

MÜLLER-LIEBENAU, I. 1969. Revision der Europäischen Arten der Gattung Baetis 
Leach, 1815 (Insecta, Ephemeroptera). Gewässer und Abwässer, 48/49: 1-214.

MUÑOZ, I. \& N. PRAT. 1994. Macroinvertebrate community in the lower Ebro river (NE Spain). Hydrobiologia, 286: 65-78. DOI: 10.1007/BF00008498

MUÑOZ, I. \& N. PRAT. 1996. Effects of water abstraction and pollution on macroinvertebrate community in a Mediterranean river. Limnetica, 12: 9-16.

NEBRA, A., N. CAIOLA \& C. IBÁÑEZ. 2011. Community structure of benthic macroinvertebrates inhabiting a highly stratified Mediterranean estuary. Scientia Marina, 75: 577-584. DOI: 10.3989/scimar.2011.75n3577

NOCENTINI, A. M. \& C. N. DELLE RICERCHE. 1985. Chironomidi, 4 (Diptera. Chironomidae. Chironominae, larve). In: Guide per il riconoscimento delle specie animali delle acque interne italiane. Ruffo, S. (ed.) 186. CNR, AQ/1/233. Verona, Italy.

OLDEN, J. D., N. L. POFF \& K. R. BESTGEN. 2006. Life-history strategies predict fish invasions and extirpations in the Colorado River Basin. Ecological Monographs, 76: 25-40. DOI: $10.1890 / 05-0330$

OLIVEIRA, S. V. \& R. M. V. CORTES. 2005. A biologically relevant habitat condition index for streams in northern Portugal. Aquatic Conservation. Marine and Freshwater Ecosystems, 15: 189-210. DOI: 10.1890/05-0330

OSCOZ, J., J. GOMA, L. ECTOR, J. CAMBRA, M. PARDOS \& C. DURAN. 2007. A comparative study of the ecological state of the Ebro watershed rivers by means of macroinvertebrates and diatoms. Limnetica, 26: 143-158.

PACE, G., V. DELLA BELLA, M. BARILE, P. ANDREANI, L. MANCINI \& C. BELFIORE. 2012. A comparison of macroinvertebrate and diatom responses to anthropogenic stress in small sized volcanic siliceous streams of Central Italy (Mediterranean Ecoregion). Ecological Indicators, 23: 544-554. DOI: 10.1016/j.ecolind.2012.05.010

POFF, N. L., J. D. ALLAN, M. B. BAIN, J. R. KARR, K. L. PRESTEGAARD, B. D. RICHTER, R. E. SPARKS \& J. C. STROMBERG. 1997. The natural flow regime. BioScience, 47: 769-784. DOI: 10.2307/1313099
POFF, N. L. \& J. K. H. ZIMMERMAN. 2010. Ecological responses to altered flow regimes: a literature review to inform the science and management of environmental flows. Freshwater Biology, 55: 194-205. DOI: 10.1111/j.13652427.2009.02272.x

PRATS, J., R. VAL, J. ARMENGOL \& J. DOLZ. 2010. Temporal variability in the thermal regime of the lower Ebro River (Spain) and alteration due to anthropogenic factors. Journal of Hydrology, 387: 105-118. DOI: 10.1016/j.jhydrol.2010.04.002

PROPST, D. L. \& K. B. GIDO. 2004. Responses of native and nonnative fishes to natural flow regime mimicry in the San Juan River. Transactions of the American Fisheries Society, 133: 922-931. DOI: 10.1577/T03-057.1

PRYGIEL, J. \& M. COSTE. 1993. The assessment of water quality in the Artois-Picardie water basin (France) by the use of diatom indices. Hydrobiologia, 269: 343-349. DOI: 10.1007/978-94-017-3622-0_36

PUCKRIDGE, J., F. SHELDON, K. F. WALKER \& A. BOULTON. 1998. Flow variability and the ecology of large rivers. Marine and freshwater research, 49: 55-72. DOI: 10.1071/MF94161

QUEVAUVILLER, P., U. BORCHERS, C. THOMPSON \& T. SIMONART. 2008. The water framework directive: ecological and chemical status monitoring. Wiley. Chichester, UK.

QUEVEDO, L. 2015. Effects of global change on benthic communities of the lower Ebro River: implications for the assessment of the ecological status. PhD Thesis. URV, Tarragona, Spain.

RENBERG, I. 1990. A procedure for preparing large sets of diatom slides from sediment cores. Journal of Paleolimnology, 4: 87-90. DOI: 10.1007/BF00208301

ROSENBERG, D. M. \& V. H. RESH. 1993. Freshwater biomonitoring and benthic macroinvertebrates. Chapman \& Hall. New York, USA.

ROSGEN, D. L. 1994. A classification of natural rivers. Catena, 22: 169-199. DOI: 10.1016/0341-8162(94)90001-9

ROSSARO, B. 1982. Chironomidi 2 (Diptera, 
Chironomidae: Orthocladiinae). In: Guide per il riconoscimento delle specie animali delle acque interne italiane. Ruffo, S. (ed.) 80. CNR, AQ/1/171 Verona, Italy.

ROVIRA, L., R. TROBAJO \& C. IBÁÑEZ. 2009. Periphytic diatom community in a Mediterranean salt wedge estuary: the Ebro Estuary (NE Iberian Peninsula). Acta Botanica Croatica, 68: 285-300.

ROVIRA, L., R. TROBAJO \& C. IBÁNEZ. 2012a. The use of diatom assemblages as ecological indicators in highly stratified estuaries and evaluation of existing diatom indices. Marine Pollution Bulletin, 64: 500-511. DOI: 10.1016/j.marpolbul.2012.01.005

ROVIRA, L., R. TROBAJO, M. LEIRA \& C. IBÁÑEZ. 2012b. The effects of hydrological dynamics on benthic diatom community structure in a highly stratified estuary: the case of the Ebro Estuary (Catalonia, Spain). Estuarine, Coastal and Shelf Science, 101: 1-14. DOI: 10.1016/j.ecss.2011.12.033

SABATER, S., J. ARTIGAS, C. DURÁN, M. PARDOS, A. M. ROMANÍ, E. TORNÉS \& I. YLLA. 2008. Longitudinal development of chlorophyll and phytoplankton assemblages in a regulated large river (the Ebro River). Science of the Total Environment, 404: 196-206. DOI: 10.1016/j.scitotenv.2008.06.013

SHERWOOD, A. R., T. L. RINTOUL, K. M. MÜLLER \& R. G. SHEATH. 2000. Seasonality and distribution of epilithic diatoms, macroalgae and macrophytes in a spring-fed stream system in Ontario, Canada. Hydrobiologia, 435: 143-152. DOI: 10.1023/A:1004011613137

SOININEN, J. \& P. ELORANTA. 2004. Seasonal persistence and stability of diatom communities in rivers: are there habitat specific differences? European Journal of Phycology, 39: 153-160. DOI: 10.1080/0967026042000201858

SOININEN, J. \& K. KÖNÖNEN. 2004. Comparative study of monitoring South-Finnish rivers and streams using macroinvertebrate and benthic diatom community structure. Aquatic Ecology, 38: 63-75. DOI: 10.1023/B:AECO. 0000021004.06965.bd

SOSTOA, A., N. CAIOLA, F. CASALS, E. GARCÍA-BERTHOU, C. ALCARAZ, L. BENEJAM, A. MACEDA, C. SOLÀ \& A.
MUNNÉ. 2010. Adjustment of the Index of Biotic integrity (IBICAT) based on the use of fish as indicators of the environmental quality of the rivers of Catalonia. Agència Catalana de l'Aigua, Departament de Medi Ambient i Habitatge, Generalitat de Catalunya, (In Catalan). Barcelona, Spain.

STAMOU, G., G. STAMOU, E. PAPATHEODOROU, M. ARGYROPOULOU \& S. TZAFESTAS. 2004. Population dynamics and life history tactics of arthropods from Mediterranean-type ecosystems. Oikos, 104: 98-108. DOI: 10.1111/j.0030-1299.2004.12382.x

STATZNER, B., J. A. GORE \& V. H. RESH. 1988. Hydraulic stream ecology: observed patterns and potential applications. Journal of the North American Benthological Society, 7 : 307-360. DOI: 10.2307/1467296

STATZNER, B., B. BIS, S. DOLÉDEC \& P. USSEGLIO-POLATERA. 2001. Perspectives for biomonitoring at large spatial scales: a unified measure for the functional composition of invertebrate communities in European running waters. Basic and Applied Ecology, 2: 73-85. DOI: 10.1078/1439-1791-00039

SUREN, A. M. \& I. G. JOWETT. 2006. Effects of floods versus low flows on invertebrates in a New Zealand gravel-bed river. Freshwater Biology, 51: 2207-2227. DOI: 10.1111/j.13652427.2006.01646.x

TACHET, H., P. RICHOUX, M. BOURNAUD \& P. USSEGLIO-POLATERA. 2000. Invertébrés d'eau douce: systématique, biologie, écologie. CNRS éditions. Paris, France.

TANG, T., S. Q. NIU \& D. DUDGEON. 2013. Responses of epibenthic algal assemblages to water abstraction in Hong Kong streams. Hydrobiologia, 703: 225-237. DOI: 10.1007/ s10750-012-1362-z

TORNÉS, E., J. CAMBRA, J. GOMÀ, M. LEIRA \& S. SABATER. 2007. Indicator taxa of benthic diatom communities: a case study in Mediterranean streams. Annales de Limnologie - International Journal of Limnology, 43: 1-11. DOI: 10.1051/limn/2007023

TORRISI, M., S. SCURI, A. DELL'UOMO \& M. COCCHIONI. 2010. Comparative monitoring by means of diatoms, macroinvertebrates and chemical parameters of an Apennine water- 
course of central Italy: The river Tenna. Ecological Indicators, 10: 910-913. DOI: 10.1016/j.ecolind.2010.01.010

TRIEST, L., P. KAUR, S. HEYLEN \& N. DE PAUW. 2001. Comparative monitoring of diatoms, macroinvertebrates and macrophytes in the Woluwe River (Brussels, Belgium). Aquatic Ecology, 35: 183-194. DOI: 10.1023/A:1011468615246

TUPINAMBÁS, T. H., R. M. V. CORTES, S. G. VARANDAS, S. J. HUGHES, J. S. FRANÇA \& M. CALLISTO. 2014. Taxonomy, metrics or traits? Assessing macroinvertebrate community responses to daily flow peaking in a highly regulated Brazilian river system. Ecohydrology, 7: 828-842. DOI: 10.1002/eco. 1406

TUPINAMBÁS, T. H., R. M. V. CORTES, S. J. HUGHES, S. G. VARANDAS \& M. CALLISTO. 2015. Macroinvertebrate responses to distinct hydrological patterns in a tropical regulated river. Ecohydrology, 9: 460-471. DOI: 10.1002/eco.1649

URREA, G. \& S. SABATER. 2009. Epilithic diatom assemblages and their relationship to environmental characteristics in an agricultural watershed (Guadiana River, SW Spain). Ecological Indicators, 9: 693-703. DOI: 10.1016/j.ecolind.2008.09.002

VAN DAM, H., A. MERTENS \& J. SINKELDAM. 1994. A coded checklist and ecological indicator values of freshwater diatoms from the Netherlands. Netherland Journal of Aquatic Ecology, 28: 117-133. DOI: 10.1007/ BF02334251

VAN DAM, H., C. STENGER-KOVÁCS, É. ÁCS, G. BORICS, K. BUCZKÓ, É. HAJNAL, É. SORÓCZKI-PINTÉR, G. VÁRBÍRÓ, B. TÓTHMÉRÉSZ \& J. PADISÁK. 2007. Implementation of the European Water Framework Directive: Development of a system for water quality assessment of Hungarian running waters with diatoms. In: Proceedings of 6th International Symposium on Use of Algae for Monitoring Rivers, Hungary, Balatonfüred. Ács, É., K. T. Kiss \& J. Padisák (eds.): 339-364. Large Rivers, 17.

VARANDAS, S. G. \& R. M. V. CORTES. 2010. Evaluating macroinvertebrate biological metrics for ecological assessment of streams in northern Portugal. Environmental Monitoring and Assessment, 166: 201-221. DOI: 10.1007/s10661-009-0996-4

VIEIRA, R. 2000. Las larvas de los tricópteros de Galicia (Insecta: Trichoptera). $\mathrm{PhD}$ Thesis. Universidad de Santiago de Compostela, Spain.

VIVAS, S., J. CASAS, I. PARDO, S. ROBLES, N. BONADA, A. MELLADO, N. PRAT, J. ALBA-TERCEDOR, M. ÁLVAREZ \& M. D. M. BAYO. 2002. Aproximación multivariante en la exploración de la tolerancia ambiental de las familias de macroinvertebrados de los ríos mediterráneos del proyecto GUADALMED. Limnetica, 21: 149-173.

WARD, J. V. \& J. A. STANFORD. 1983. The serial discontinuity concept of lotic ecosystems. In: Dynamics of lotic ecosystems. Fontaine III, T. D. \& S. M. Bartell (eds.): 29-42. Ann Arbor Science. Ann Arbor, Michigan, USA.

WENTWORTH, C. K. 1922. A scale of grade and class terms for clastic sediments. The Journal of Geology, 30: 377-392.

WHITEHURST, I. \& B. LINDSEY. 1990. The impact of organic enrichment on the benthic macroinvertebrate communities of a lowland river. Water Research, 24: 625-630. DOI: 10.1016/0043-1354(90)90195-C

WHITTON, B. A., E. ROTT \& G. FRIEDRICH. 1991. Use of algae for monitoring rivers. Journal of Applied Phycology, 3(3): 287-287. DOI: $10.1007 / \mathrm{BF} 00003588$ 